Regular Research Article

\title{
Estimation of Above-Ground Mangrove Biomass Using Landsat-8 Data- Derived Vegetation Indices: A Case Study in Quang Ninh Province, Vietnam
}

\author{
Hai-Hoa Nguyen ${ }^{1 *}$, Huy Duc Vu ${ }^{1,2}$, and Achim Röder ${ }^{2}$ \\ ${ }^{1}$ Vietnam National University of Forestry, Faculty of Forest Resources and Environmental Management. \\ ${ }^{2}$ University of Trier, Faculty of Regional and Environmental Science, Department of Environmental Remote \\ Sensing and Geoinformatics. Behringstr, Germany. \\ *Correspondence author: Hai-Hoa Nguyen- hoanh@vnuf.edu.vn; Tel.: +84-977-689-948
}

\begin{abstract}
This study aimed to map the status of mangrove forests over the coasts of Hai Ha District and Mong Cai City in Quang Ninh Province by using 2019 Landsat-8 imagery. It then developed the AGB estimation model of mangrove forests based on the AGB estimation-derived plots inventory and vegetation indices-derived from Landsat-8 data. As results, there were five land covers identified, including mangrove forests, other vegetation, wetlands, built-up, and water, with the overall accuracy assessments of $80.0 \%$ and Kappa coefficient of 0.74 . The total extent of mangrove forests was estimated at 4291.2 ha. The best AGB estimation model that was selected to estimate the $A G B$ and $A G C$ of mangrove forests for the whole coasts of Hai Ha District and Mong Cai City is $A G B=30.38+911.95^{*} S A V I\left(R^{2}=0.924\right.$, Pvalue $\left.<0.001\right)$. The model validation assessment has confirmed that the selected $A G B$ model can be applied to Hai Ha and Mong Cai coasts with the mean difference between AGB observed and AGB predicted at $16.0 \%$. This satisfactory AGB model also suggests a good potential for $A G B$ and $A G C$ mapping, which offer the carbon trading market in the study site. As the $A G B$ model selected, the total $A G B$ and $A G C$ of mangrove forests were estimated at about $14,600,000$ tons and 6,868,076 tons with a range of from $94.0-432.0$ tons ha ${ }^{-1}$, from $44.2-203.02$ tons $\mathrm{ha}^{-1}$, respectively. It also suggests that the newly-developed AGB model of mangrove forests can be used to estimate AGC stocks and carbon sequestration of mangrove forests for C-PFES in over the coasts of Hai Ha District and Mong Cai City, which is a very importantly financial source for mangrove forest managers, in particular for local mangrove protectors.
\end{abstract}

Keywords: Above-ground biomass; Carbon stocks; Coastal zones; Landsat-8; Mangrove forests; Model; Remote sensing; Vegetation indices.

\section{Introduction}

Mangrove forests are salt-tolerant evergreen species found along sheltered coastlines, shallowwater lagoons, estuaries, and rivers or deltas (Thom, 1984; Blasco et al.,1998; Huong et al., 2021). They grow as trees or shrubs according to the climate, salinity of the water, topography, and edaphic features of the area (Lugo and Snedaker, 1975; Tomlinson, 1986; Aksornkoae, 1993; Huong et al., 2021). Mangrove forests are geographically distributed in the tropical and subtropical areas of the world between approximately $30^{\circ} \mathrm{N}$ and $30^{\circ} \mathrm{S}$, and mangrove ecosystem is the bridge between the land and sea (Alongi, 2009). Mangrove forests are also well-known as important coastal resources in the tropics due to their provision of wood for construction and fuel, habitats of coastal marine organisms, carbon storage in biomass and soil, protection of coastal habitants from strong wind actions during typhoons, prevention of coastal erosion (Alongi, 2009; Donato et al., 2011). However, there is a large reduction of the global mangrove cover due to continuous conversion to nonmangrove land uses, such as aquaculture and shrimp farm expansion, agricultural development, and mangrove clearance for coastal human settlements (FAO, 2007; Hai-Hoa et al., 2013; Hai- Hoa, 2014; Hai-Hoa et al., 2020a; Hai-Hoa et al., 2020b). Therefore, it is very important to monitor mangrove forests against land-use change and detect mangrove deforestation and degradation.

Empirical quantification of the carbon stocks of mangrove forests and land uses are very crucial to provide emission estimates based on actual measures of carbon stocks and reduce the 
uncertainty of the estimate (Hyyppä et al., 2000; Steininger, 2000; Pham et al., 2020). Above-ground biomass (AGB) is one of the important carbon pools in mangrove forests (Kauffman and Donato, 2012; Howard et al., 2014). In addition, there has been an increasing number of literature on mangrove biomass and their carbon stocks recently (Tue et al., 2014; Stringer et al., 2015; Vien et al., 2016). However, a few studies have quantified mangrove biomass and carbon stocks using a combination of remote sensing and field-based data (Lu et al., 2010; Jachowski et al., 2013; Dube et al., 2016). Remote sensing technology offers scientists and major planners to have alternative options of strategies in the management of talent natural resources and environment (Kuenzer et al., 2011; Hu et al., 2020). The use of remote sensing techniques offers the cost and time effectiveness in conducting large-scale mangrove biomass assessments (Kovacs et al., 2010; Giri, 2016; Castillo et al., 2017; Cissell et al., 2018; Giri, 2021). For this reason, the relationships between field-measured biomass data and remote sensing data are assessed and used to develop a model that allows predicting mangrove biomass of different locations of the study sites. The outcome of remote sensing-based mangrove biomass estimation is spatially explicit patterns of the total AGB mangrove forests and its variations over the studied areas (Castillo et al., 2017).

Remarkable studies on estimating biomass and carbon stocks have summarized and listed a number of general equations that can be used to estimate the biomass of living trees in the mangrove forests over the world (e.g. Li et al., 2007; Kauffman and Donato, 2012; Sinha et al., 2015, Timothy et al., 2016). A recent study by Hamdan et al. (2013) has shown that carbon stocks of Matang mangroves, Malaysia ranged from 1.03 to 263.65 tons ha ${ }^{-1}$ and 1.01 to 259.68 tons ha ${ }^{-1}$ in 1991 and 2011, respectively.

In Vietnam, Pham et al. (2017) used SPOT-4 and 5 images in combination with machine learning algorithms to estimate and analyze the change of AGB between 2010 and 2011 in Can Gio mangrove forests. The total AGB was calculated at 9,391,515 ha in 2011, increased by 820,136 tons in comparison with 2010. Pham and Yoshino (2018) used ALOS-2 PALSAR data to estimate the AGB of mangrove forests in Hai Phong City, Vietnam. This study found that the average AGB was approximately 39 tons ha ${ }^{-1}$ for Sonneratia caseolaris, and 100 tons ha ${ }^{-1}$ for Kandelia obovata. Bao and Hoa (2018) used Sentinel-1 and Sentinel-2 satellite data to estimate the biomass of mangrove forests in Tien Lang District, Hai Phong Province. Their study showed that Sentinel-1 backscatters were unable to generate a reliable regression model to estimate biomass due to relatively low $\mathrm{R}^{2}$. However, using vegetation indices (NDVI, SAVI) has offered a good regression model to estimate biomass ( $R^{2}$ for NDVI is 0.719 , and $R^{2}$ for SAVI is 0.705). Similarly, Long et al. (2019) developed the linear regression model to estimate the AGB of mangrove forests in Thai Binh Province, Vietnam. The relationship between field biomass and vegetation indices was defined with RMSE \pm 12.08 tons ha $^{-1}$. In general, all previous studies conducted are located in Hai Phong City, Thai Binh, and Nam Dinh Provinces. Information about biomass and carbon stocks in Quang Ninh Province, especially in Hai Ha District and Mong Cai City remains unanswered. Allometric equations for both above-ground biomass ( $A G B$ ) and below-ground biomass (BGB) estimation of mangrove forests still remain limited and unclear in Quang Ninh Province. Therefore, the AGB estimation based on remote sensing data and vegetation indices offers the potential cost reduction and improves estimation accuracy in Quang Ninh Province (Heumann, 2011, Hamdan et al., 2014; Kumar and Mutanga, 2017; Hu et al., 2020). In this study, we evaluated the ability of Landsat-8 for the retrieval and predictive mapping of AGB of mangrove forests in Quang Ninh Province. The specific objectives of the study included the following: (1) to map the status of coastal land use and land covers, including mangrove forests based on Landsat- 8 imagery, (2) to determine and model the relationship between field-measured $A G B$ and Landsat-8- derived vegetation indices from mangrove forests, (3) to evaluate the accuracy of the predictive models of $A G B$ and to create the $A G B$ and $A G C$ maps based on the selected $A G B$ model. We developed and evaluated the AGB model of mangrove forests and predictive AGB maps from Landsat-8- derived vegetation indices. This study attempted to develop remote sensing-based AGB predictive mapping techniques for mangrove forests, thus contributing to the development of C-PFES in Vietnam. 


\section{Materials and Methods}

\subsection{Study site}

Quang Ninh geographically locates in the North-eastern Vietnam. It borders China in the north. The total area is $6177.7 \mathrm{~km}^{2}$, with a coastline of $250 \mathrm{~km}$ long. The total population is estimated at approximately 1.2 million people. Mangrove forests mainly grow along the shoreline of Quang Ninh Province. This study has focused on mangrove forests along the coasts of Hai Ha District and Mong Cai City, Quang Ninh Province (Fig. 1).

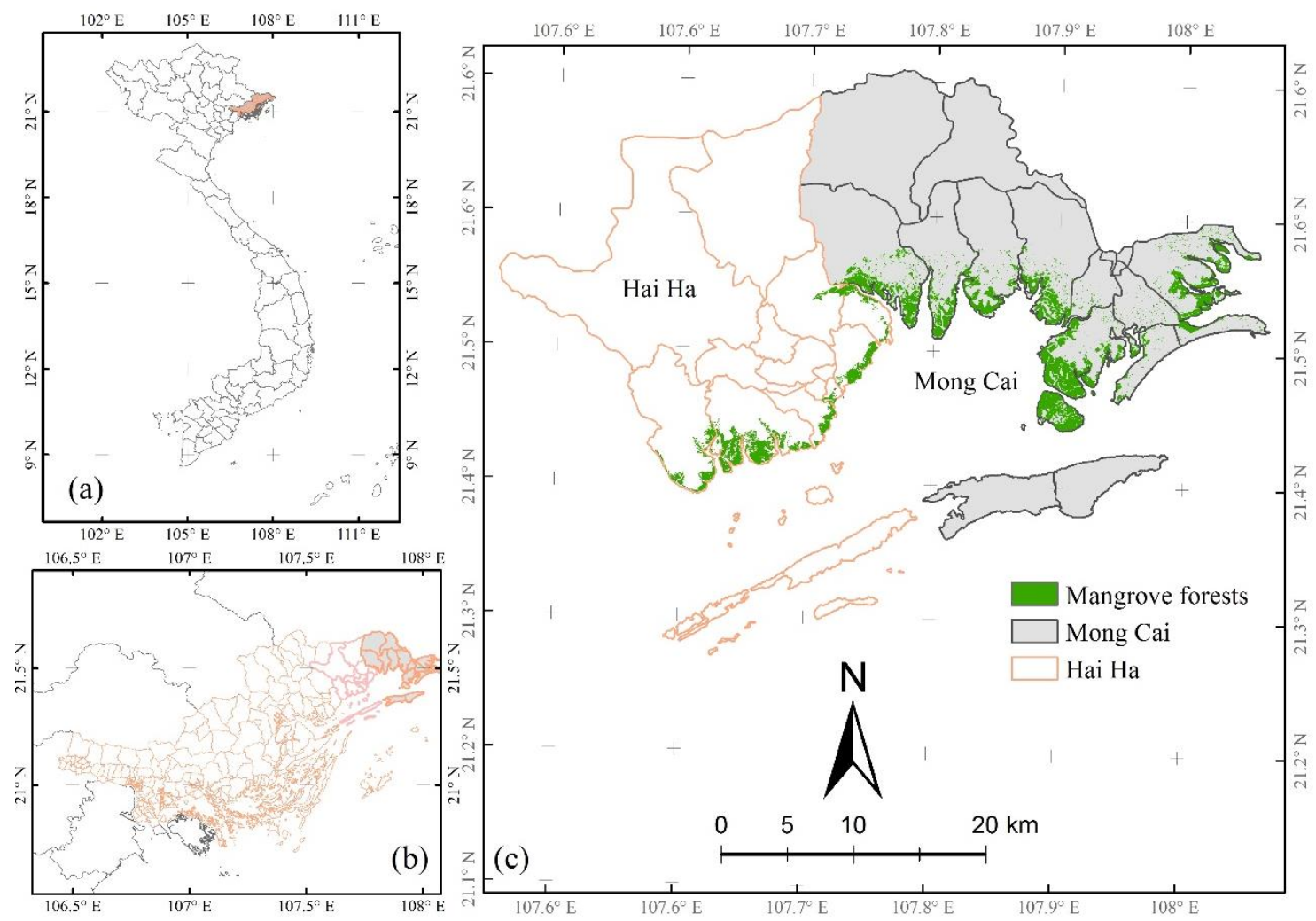

Figure 1. Study site: (a) The geographical location of Quang Ninh Province in Vietnam, (b) Geographical location of Hai Ha District and Mong Cai City, (c) Coastal study sites with mangrove forests extracted from Landsat-8 $15^{\text {th }}$ August 2019.

According to the recent report of Quang Ninh Forest Protection Department (2018), the total areas of mangrove forests in Hai Ha District are estimated at approximately 1392.5 ha, while Mong Cai City has around 2687.1 ha (Table 2). The main mangrove species in these areas include Kandelia obovata, Rhizophora stylosa, Avicennia marina, Sonneratia caseolaris, Bruguiera gymnorrhiza, and Aegiceras coniculatum.

Table 1. Mangrove extents in Hai Ha District and Mong Cai city in 2018.

\begin{tabular}{|c|c|c|c|c|c|}
\hline Study site & Communes & Area (ha) & Study site & Communes & Area (ha) \\
\hline \multirow{6}{*}{$\begin{array}{l}\text { Hai Ha } \\
\text { District }\end{array}$} & Duong Hoa & 184.6 & \multirow{6}{*}{$\begin{array}{c}\text { Mong Cai } \\
\text { City }\end{array}$} & Hai Dong & 309.6 \\
\hline & Tien Toi & 52.5 & & Binh Ngoc & 50.8 \\
\hline & Quang Phong & 832.7 & & Hai Hoa & 586.0 \\
\hline & Quang Minh & 167.9 & & Hai Tien & 318.2 \\
\hline & Quang Thang & 115.3 & & Hai Xuan & 30.3 \\
\hline & Quang Thanh & 39.6 & & Hai Yen & 405.7 \\
\hline \multirow{5}{*}{\multicolumn{4}{|c|}{$\begin{array}{l}\text { Source: Quang Ninh FPD (2018). A part of the mangrove } \\
\text { extents in Quang Dien commune, belonged to Hai Ha } \\
\text { District was not included in Table } 1 .\end{array}$}} & Ninh Duong & 5.9 \\
\hline & & & & Quang Nghia & 526.6 \\
\hline & & & & Tra Co & 69.2 \\
\hline & & & & Van Ninh & 383.1 \\
\hline & & & & Vinh Trung & 1.7 \\
\hline
\end{tabular}




\subsection{Methods}

The details of Landsat- 8 classification method used for mapping the extent of mangrove forests are schematically presented in Fig. 2.

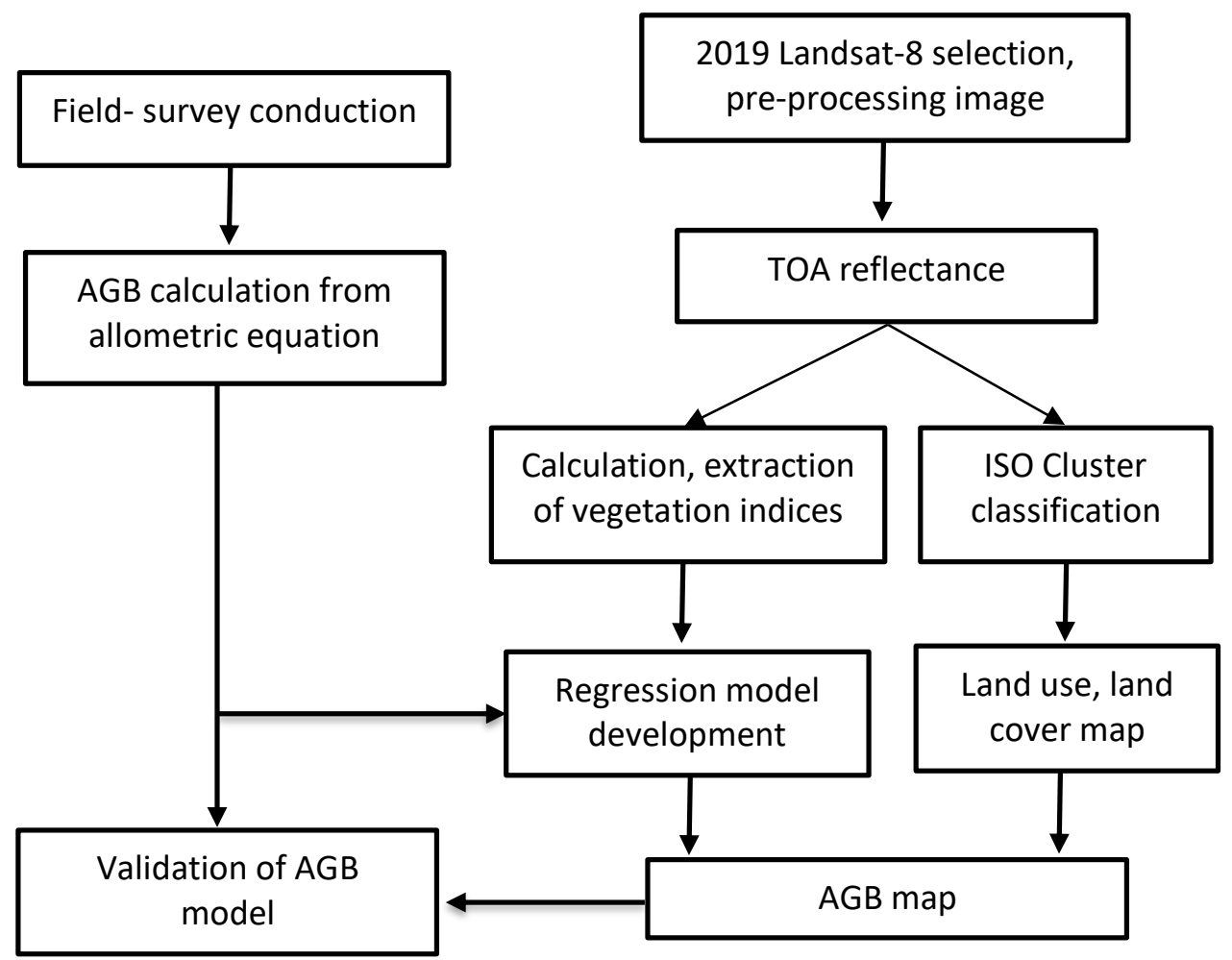

Figure 2. The flowchart of study methods used for mapping and calculating the AGB of mangrove forests.

\subsubsection{Data collection}

This study used the Landsat-8 image captured on $15^{\text {th }}$ August 2019 , which covering over the coasts of Hai Ha District and Mong Cai City, Quang Ninh Province (Table 2). The details of Landsat-8 in 2019 and other remote sensing and GIS data, such as PlanetScope in 2019 and land use and land cover map in $\mathbf{2 0 1 0}$ were used to map land use and land cover, including mangrove forests as presented in Table 2.

Table 2. Remote sensing data collected and used in this study.

\begin{tabular}{clccc}
\hline ID & \multicolumn{1}{c}{ Image codes } & Date & Resolution $(\mathbf{m})$ & Remarks \\
\hline $1^{\text {a }}$ & LC08125045_20190815T1 & $15 / 08 / 2019$ & 30 & Landsat-8 \\
$2^{\text {b }}$ & 20190807_031733_105c_3B_AnalyticMS & $07 / 08 / 2019$ & 3 & PLanetScope \\
& 20190807_031735_105c_3B_AnalyticMS & $07 / 08 / 2019$ & 3 & PlanetScope \\
& 20190815_030220_0f3f_3B_AnalyticMS & $15 / 08 / 2019$ & 3 & PlanetScope \\
& 20190810_031713_1061_3B_AnalyticMS & $10 / 08 / 2019$ & 3 & PlanetScope \\
& 20190820_021002_0f2b_3B_AnalyticMS & $20 / 08 / 2019$ & 3 & PlanetScope \\
$3^{c}$ & Land use and land cover map & 2010 & \multirow{2}{*}{$1: 50,000$} & Quang Ninh \\
& & & & DARD \\
\hline
\end{tabular}

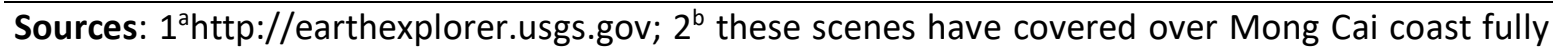
and Hai Ha coast partially, https://www.planet.com; 3'Quang Ninh DARD- Quang Ninh Department of Agriculture and Rural Development (2010)

\subsubsection{Field data collection}

The field survey was conducted in the late October 2019. Ten sampling plots were set up each Hai Ha District and Mong Cai City (a total of 20 plots) with a dimension of $30 \mathrm{~m} \times 30 \mathrm{~m}$ (equivalent to $900 \mathrm{~m}^{2}$ ) (Fig. 3). In 20 plots, five plots were selected and kept for the model validation (Plots 4, 8, 12,16 , and 20). Within each plot, there were three sub-plots $(A, B, C)$ with a dimension of $10 \mathrm{~m} \times 10$ 
$\mathrm{m}$ (equivalent $100 \mathrm{~m}^{2}$ ) set up to measure main mangrove structures, including species, tree height $(\mathrm{H})$, and diameter at the breast height $(\mathrm{DBH}, 1.3 \mathrm{~m})$, tree density.

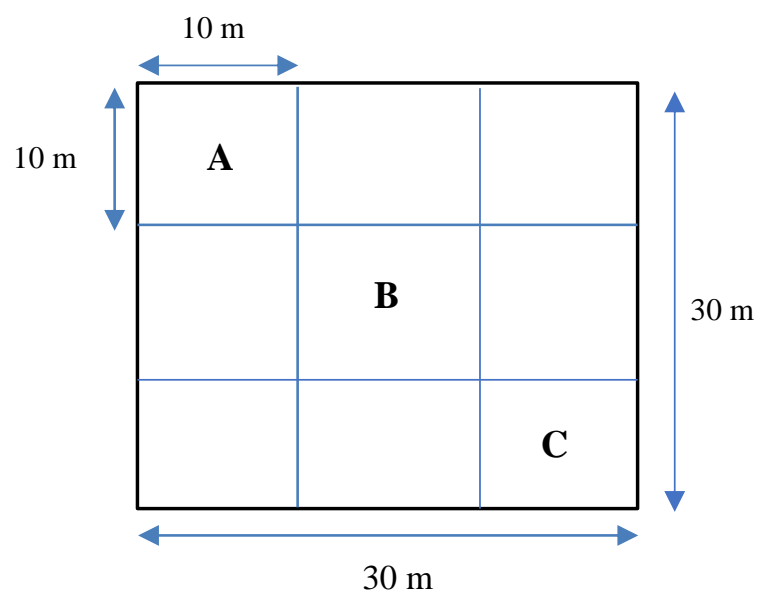

Figure 3. Layouts of sampling plots and subplots $\left(100 \mathrm{~m}^{2}\right)$ in the coasts of Hai Ha and Mong Cai.

\subsubsection{Data pre-processing}

In this study, 2019 Landsat-8 image was required to radiometric calibration. Gain bias correction scattering effects and corrections of the sun angle are necessary and mangrove cover analysis is conducted (Norjamaki and Tokola, 2007; Gupta et al., 2018; Hai-Hoa et al., 2020a). Radiometric calibration of Landsat-8 bands was applied to convert digital number values into top of the atmosphere spectral radiance (TOA), then bands were converted to TOA planetary reflectance (Chander et al., 2009; Gupta et al., 2018; Hai-Hoa et al., 2020b). Atmospheric and radiometric corrections were all employed to remove errors and increase accuracies by using the Spatial Analyst Tools in ArcGIS 10.6. (Hai-Hoa and Binh, 2016, Hai-Hoa et al., 2020a). In addition, five Landsat-8 bands (BLUE, GREEN, RED, NIR and SWIR) were used for classification and visual interpretation approaches (Table 2). Therefore, these bands were staked into composite image, then were masked to both include areas where mangrove forests are more likely to be found, such as intertidal and low-lying areas, exclude areas where mangrove forests are not naturally present, like far inland, highlands and open ocean (Long and Giri, 2011; Hai-Hoa et al., 2020a). In this study, the aim of masking possible mangrove areas was to reduce unnecessary data volume and increase overall classification accuracy (Hai-Hoa et al., 2020b). To mask the possible mangrove areas accurately, 2019 PlanetScope $(3 \mathrm{~m} \times 3 \mathrm{~m})$ and Google Earth were used to delineate the boundary of possible mangrove areas from other coastal land use and land cover (Hai-Hoa et al., 2020a). The delineated boundary was then checked with the field survey to ensure every possible mangrove areas included within the boundary. Additionally, the 30-m SRTM DEM data, DEM-derived slope and elevation were used to mask out the areas of high elevation and step slope where mangrove forests are not likely to be present (Chen et al., 2017; Hai-Hoa et al., 2020a).

\subsubsection{Remotely sensed data processing and image classification}

Image classification was processed to map the extent of mangrove forests in 2019 by using the unsupervised classification. The study applied the k-means clustering algorithm to produce 36 userdefined classes with the iteration number of 5 (Hai-Hoa et al., 2020a). The generated classes were then compared with the field survey data and finally merged them into 5 main classes, namely mangrove forests, other vegetation (terrestrial trees and rice paddy field), mudflats and wetlands, built-up and infrastructure areas, and water.

\subsubsection{Calculation of vegetation indices}

In this study, 4 vegetation indices were calculated and used for the AGB model development (Table 3). Vegetation indices (VIs) were extracted and combined with calculated AGB values from the allometric equation (15 plots) to generate estimated AGB models. 
Table 3. Equations of vegetation indices used for estimating mangrove forests and the AGB model development.

\begin{tabular}{|c|c|c|c|}
\hline ID & Vegetation Indices & Equations & References \\
\hline 1 & $\begin{array}{c}\text { SR } \\
\text { (Simple Ratio) }\end{array}$ & $\mathrm{SR}=\frac{\rho_{N I R}}{\rho_{R E D}}$ & $\begin{array}{c}\text { Kongwongjan et al., (2012); Pham } \\
\text { et al., (2018) }\end{array}$ \\
\hline 2 & $\begin{array}{c}\text { NDVI } \\
\text { (Normalised } \\
\text { Difference } \\
\text { Vegetation Index) }\end{array}$ & $\mathrm{NDVI}=\frac{\rho_{N I R}-\rho_{R E D}}{\rho_{N I R}+\rho_{R E D}}$ & $\begin{array}{l}\text { Ramdani et al., (2018); Pham et } \\
\text { al., (2018); Saleh (2007) }\end{array}$ \\
\hline $3^{a}$ & $\begin{array}{c}\text { SAVI } \\
\text { (Soil Adjusted } \\
\text { Vegetation Index) }\end{array}$ & $\mathrm{SAVI}=\frac{\rho_{N I R}-\rho_{\text {Red }}}{\rho_{N i r}+\rho_{\text {Red }}+L} \times(1+L)$ & $\begin{array}{c}\text { Kongwongjan et al., (2012); Pham } \\
\text { et al., (2018) }\end{array}$ \\
\hline $4^{b}$ & $\begin{array}{c}\text { EVI } \\
\text { (Enhanced } \\
\text { Vegetation Index })\end{array}$ & $\begin{array}{l}\text { EVI } \\
=G \frac{\rho_{\text {NIR }}-\rho_{\text {Red }}}{\rho_{\text {NIR }}+C_{1} \times \rho_{\text {Red }}-C_{2} \times \rho_{\text {Blue }}+L} \\
\mathrm{L=1}, \mathrm{C} 1=6, \mathrm{C} 2=7.5, \mathrm{G}=2.5\end{array}$ & $\begin{array}{l}\text { Huete et al., (2002); Pham et al., } \\
\text { (2018) }\end{array}$ \\
\hline
\end{tabular}

In this study: $3^{\mathrm{a}}: \mathrm{L}=0.5$ was used; $4^{\mathrm{a}}: \mathrm{L}=1, \mathrm{C} 1=6, \mathrm{C} 2=7.5$, and $\mathrm{G}=2.5$ were used.

\subsubsection{Accuracy assessments}

To evaluate the accuracy of Landsat- 8 image classified and assess the accuracy of land use and land cover map in 2019, user's, producer's and overall accuracy with Kappa coefficient were derived from the error matrix. Kappa value is categorized into different groups where kappa value is less than zero, it then indicates no agreement; from 0 - 0.20 refers to a slight agreement; $0.21-0.40$ represents as a fair agreement, from 0.41 - 0.60 is considered as a moderate agreement, whereas $0.61-0.80$ is regarded as substantial, and $0.81-1.00$ refers to an almost perfect agreement (Malarvizhi et al., 2016; Dan et al., 2016). The validation GCPs were derived from the field survey in 2020; and PlanetScope and Google Earth images in 2019 (Table 2). A total of 300 ground-control points (GCPs) was randomly selected and collected by Garmin GPS map78s, which randomly distributed over the coasts of Mong Cai and Hai Ha for three main land use/cover classes. These GCPS were then used to perform accuracy assessments and estimate the Kappa coefficient. A number of 200 GPS points (equivalent to $70 \%$ of total field GPS points) were used for classification purposes and $30 \%$ of GPS points (equivalent to 100 GPS points) were used for the accuracy assessments and the Kappa coefficient generation.

\subsubsection{Estimation of Above-ground biomass (AGB)}

In this study, AGB was estimated by using the below allometric equation. This equation has been developed by Komiyama et al. (2005) and an experimental coefficient is suitable for SouthEast Asian mangrove forests with a high correlation $\left(R^{2}=0.98\right)$.

$$
B=0.251 * \rho *(D)^{2.46}
$$

Where $B$ refers to $A G B(\mathrm{~kg})$, while $D$ is the diameter at the breast height $(\mathrm{cm})$, and $\rho$ is wood density $\left(\mathrm{gram} / \mathrm{cm}^{3}\right)$. Wood density is provided by the Agroforestry center website (http://db.worldagroforestry.org//wd).

The total $A G B$ of each plot was the sum of $A G B$ in 3 sub-plots and converted into tons ha-1.

\subsubsection{AGB model development}

Linear regression model with the stepwise approach has been developed to predict the variable for estimating AGB with the help of R (Statistics Package for Social Science). Here, the AGB was taken as a dependent variable. SR, NDVI, SAVI and EVI were taken as independent variables for predicting the AGB over the coasts of Mong Cai and Hai Ha. R is multiple correlation coefficients, which are considered as a measure of the worth of the prediction of the dependent variables. The values are statistically analyzed for the creation of a model using the linear regression with the stepwise

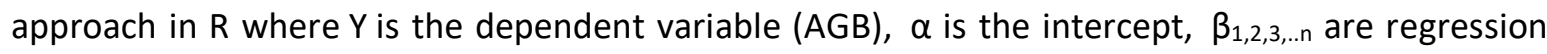
coefficients of the independent variables, and $x_{1,2,3, \ldots n}$ are independent variables (SR, NDVI, SAVI, $\mathrm{EVI})$, which would be the predictor of the dependent variable. 


$$
Y=\alpha+\beta_{1} x_{1}+\beta_{2} x_{2}+\cdots+\beta_{n} x_{n}
$$

In this study, the linear regression model between AGB and VIs was analyzed by using R-studio version 1.2.5042. The best model that has the highest coefficient determination $\left(R^{2}\right)$ and a statistical significance of $P_{\text {value }}$ would be finally selected and validated with 5 validation plots. Five validation plots were used to evaluate the accuracies of the generated model (Plots 4, 8, 12, 16, and 20).

\subsubsection{AGC (Aboveground carbon stocks) estimation}

To convert the $A G B$ of mangrove forests into $A G C$ stocks, a conversion ratio of 0.47 was applied as $A G C=A G B^{*} 0.47$ (Howard et al., 2014). To propose for C-PFES, this study calculated the total $\mathrm{CO}_{2}$ absorbed by mangrove forests using the formula: $\mathrm{CO}_{2}=$ carbon stocks (ton ha ${ }^{-1}$ ) $\times 44 / 12$ (Eggleston et al., 2006).

\section{Results and Discussions}

\subsection{Results}

\subsubsection{Accuracy assessments of land use and land cover mapping:}

This study used 100 GPS validation points collected from the ground reference data over the coast of Hai Ha and Mong Cai (Table 3). As shown in Table 4, the most classes had the levels of producer's and user's accuracies quite high (>77.8\%). Especially, the overall map accuracy was $80.0 \%$ (Table 4) with the Kappa coefficient of 0.74 . This coefficient indicates that there is a substantial agreement between data collected from the field survey and the results-derived Landsat-8 image classification (Malarvizhi et al., 2016; Dan et al., 2016). During accuracy assessments, mapping accuracy might be affected by possible mixed-pixel issues, tidal regime and cloud cover percentage (Hai-Hoa et al., 2020b). However, the overall accuracy assessment with $80.0 \%$ has confirmed that the land use and land cover mapping by Landsat- 8 are applicable over the coasts of $\mathrm{Hai} \mathrm{Ha}$ and Mong Cai, Quang Ninh Province (Hai-Hoa et al., 2020a, 2020b).

Table 4. Accuracy assessments of land use and land cover classified by unsupervised classification method in 2019.

\begin{tabular}{|c|c|c|c|c|c|c|c|}
\hline \multirow{2}{*}{ Image classified } & \multicolumn{6}{|c|}{ Reference data } & \multirow{2}{*}{$\begin{array}{c}\text { User's } \\
\text { accuracy } \\
\text { (\%) }\end{array}$} \\
\hline & Man & $\begin{array}{c}\text { Other } \\
\text { vegetation }\end{array}$ & Wetlands & Built-up & Water & $\begin{array}{c}\text { Total } \\
\text { samples }\end{array}$ & \\
\hline Man & 22 & 3 & 2 & 0 & 1 & 28 & 78.6 \\
\hline Other vegetation & 1 & 14 & 0 & 3 & 0 & 18 & 77.8 \\
\hline Wetlands & 0 & 0 & 19 & 2 & 0 & 21 & 90.5 \\
\hline Built-up & 1 & 0 & 5 & 21 & 0 & 27 & 77.8 \\
\hline Water & 0 & 0 & 2 & 0 & 4 & 6 & 66.7 \\
\hline Total samples & 24 & 17 & 29 & 26 & 4 & 100 & \\
\hline \multirow{2}{*}{ Producer's accuracy (\%) } & 91.7 & 82.4 & 67.9 & 80.8 & 80.0 & & \\
\hline & \multicolumn{7}{|c|}{ Overall accuracy: $80.0 \%$, Kappa coefficient: 0.74} \\
\hline
\end{tabular}

Man (mangrove forests); Other vegetation (banana trees, grass, bushes,...); Wetlands (Wet and bare soils, mudflats,...); Built-up (residential areas, infrastructure,...); and Water (open water areas, shrimps and ponds,...).

\subsubsection{Image classification and extraction of mangrove forests}

This study focused on the mangrove forests over the coasts of Hai Ha District and Mong Cai City, Quang Ninh Province, Vietnam. Mangrove forests were separated from other coastal land use and land covers (LULC) for estimating the AGB of mangrove forests (Fig. 4). As results, the LULC map and the extent of mangrove forests are created and shown in Fig. 4 and Fig. 5, respectively. 


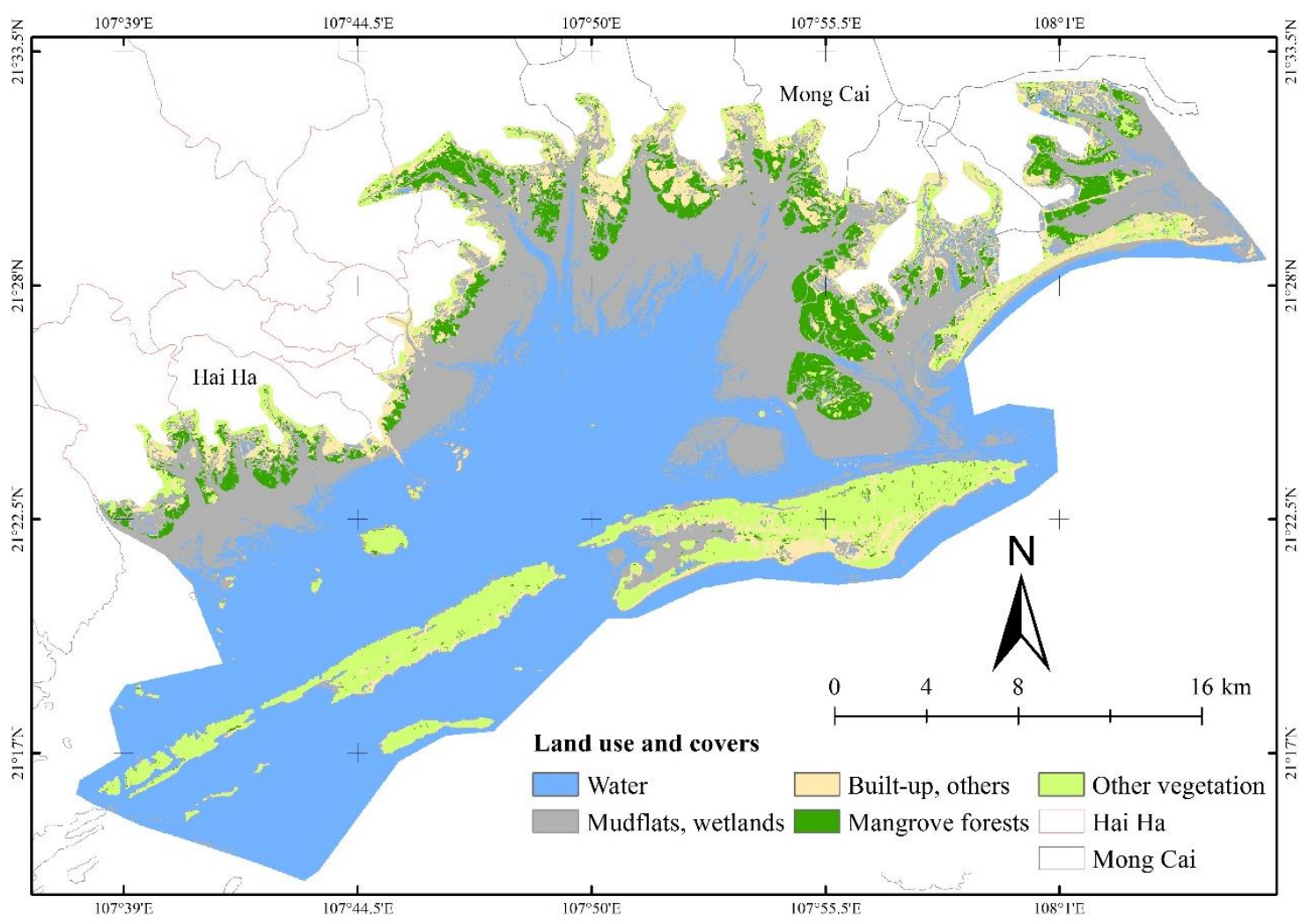

Figure 4. Land use and land cover distribution in 2019 (Landsat-8 15 August 2019).

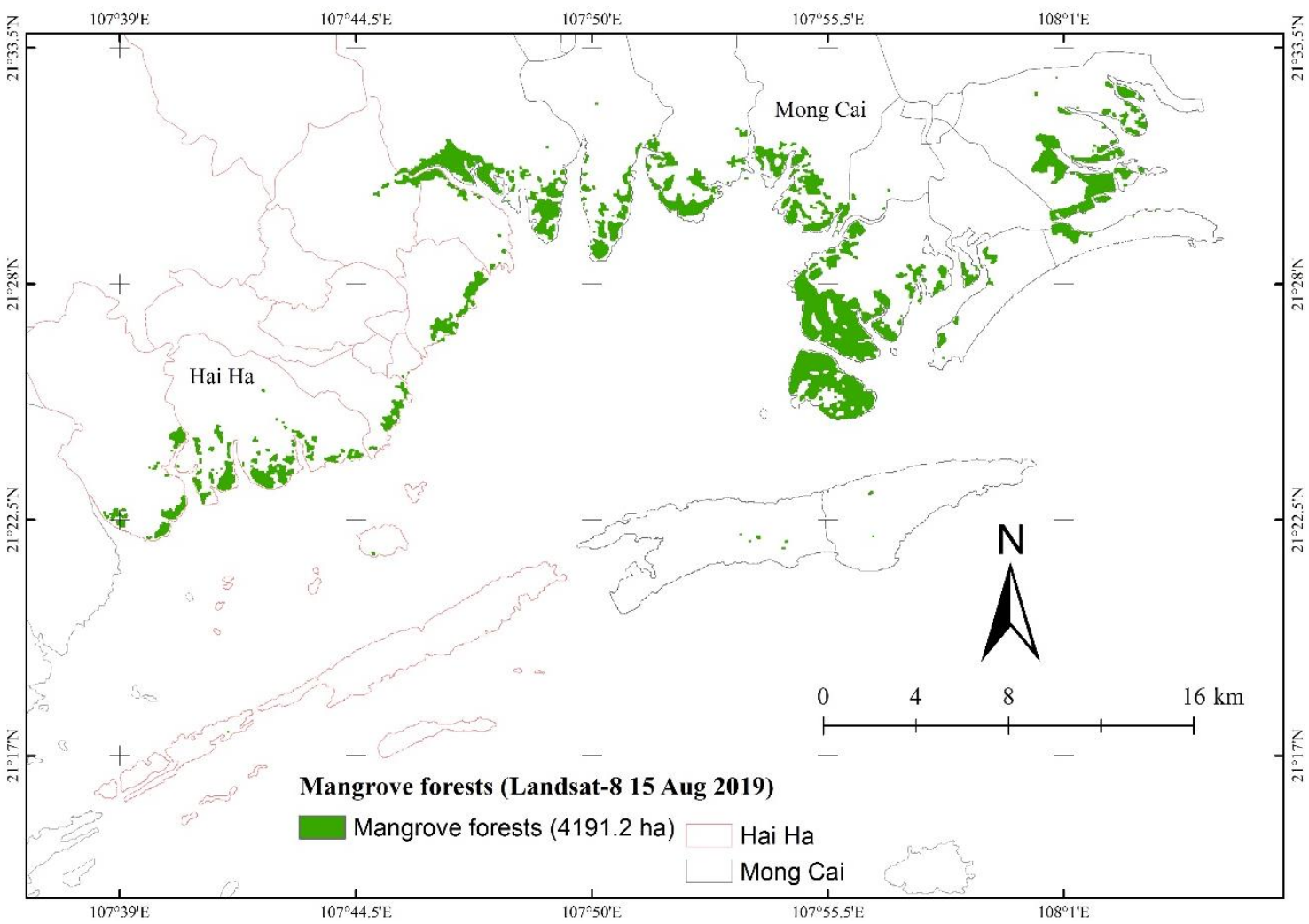

Figure 5. The extent of mangrove forests generated from Landsat-8 15 August 2019 over the coasts of Hai Ha and Mong Cai, Quang Ninh Province.

\subsubsection{Estimated $A G B$ from vegetation indices (VIs)}

This survey found that mangrove forests had a relatively high density, ranging from 7000 to 9000 trees ha $^{-1}$. There are 4 dominant species identified in these sampling plots, namely Rhizophora 
stylosa, Avicennia marina, Aegiceras coniculatum, and Kandelia obovata. Mangrove forests distribute along the coasts of Hai Ha District and Mong Cai City (Fig. 5). The total extent of the mangrove forests in the study sites (Hai Hai and Mong Cai) was estimated at 4191.2 ha (Fig. 5). As indicated in Table 5, the largest mangrove extent was experienced in Van Ninh Commune (1411.2 ha), followed by Hai Hoa, Quang Nghia and Hai Yen communes in Mong Cai coast with 522.4 ha, 470.1 ha, and 326.3 ha, respectively (Table 5). In Hai Ha coast, the largest mangrove areas were recorded in Quang Phong commune (356.9 ha), followed by Duong Hoa and Quang Minh communes with 147.6 ha and 126.6 ha, respectively.

Table 5. The extent of mangrove forests in Mong Cai and Hai Ha in 2019 (Landsat-8 $15^{\text {th }}$ August 2019).

\begin{tabular}{|c|c|c|c|c|c|}
\hline & Communes & Mangrove areas (ha) & & Communes & Mangrove areas (ha) \\
\hline \multirow{13}{*}{ 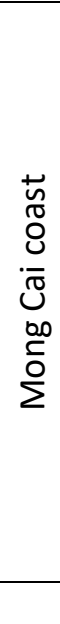 } & Binh Ngoc & 45.0 & \multirow{9}{*}{ 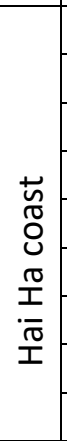 } & Cai Chien & 0.8 \\
\hline & Hai Dong & 261.7 & & Duong Hoa & 147.6 \\
\hline & Hai Hoa & 522.4 & & Phu Hai & 1.7 \\
\hline & Hai Tien & 202.4 & & Quang Minh & 126.6 \\
\hline & Hai Xuan & 45.5 & & Quang Phong & 356.9 \\
\hline & Hai Yen & 326.3 & & Quang Thang & 62.3 \\
\hline & Ninh Duong & 24.1 & & Quang Thanh & 59.1 \\
\hline & Quang Nghia & 470.1 & & Tien Toi & 66.4 \\
\hline & Tra Co & 51.3 & & Total & 821.4 \\
\hline & Van Ninh & 1411.2 & \multirow{4}{*}{\multicolumn{3}{|c|}{$\begin{array}{l}\text { Total mangrove extent of study sites: } \\
\qquad 4191.2 \text { ha }\end{array}$}} \\
\hline & Vinh Thuc & 2.97 & & & \\
\hline & Vinh Trung & 6.8 & & & \\
\hline & Total & 3369.77 & & & \\
\hline
\end{tabular}

The areas of mangrove forests illustrated in Fig. 5 were extracted to calculate vegetation indices (VIs) from Landsat-8 data. An average of AGB and VIs values in corresponding plots is presented in Table 6.

Table 6. An average of plot-derived AGB and Landsat-8-derived values of VIs.

\begin{tabular}{|c|c|c|c|c|c|c|c|}
\hline Plots & Longitude & Latitude & AGB (tons ha $^{-1}$ ) & NDVI & EVI & SAVI & SR \\
\hline 1 & 107.6608 & 21.4014 & 264.21 & 0.378 & 0.375 & 0.219 & 2.214 \\
\hline 2 & 107.6704 & 21.4015 & 276.01 & 0.464 & 0.480 & 0.273 & 2.733 \\
\hline 3 & 107.6808 & 21.4069 & 273.39 & 0.440 & 0.456 & 0.257 & 2.572 \\
\hline 4 & 107.6850 & 21.4029 & 331.80 & 0.528 & 0.562 & 0.326 & 3.240 \\
\hline 5 & 107.6814 & 21.4034 & 266.35 & 0.418 & 0.409 & 0.243 & 2.434 \\
\hline 6 & 107.6891 & 21.4055 & 310.27 & 0.502 & 0.530 & 0.309 & 3.018 \\
\hline 7 & 107.6865 & 21.4092 & 291.38 & 0.487 & 0.522 & 0.300 & 2.899 \\
\hline 8 & 107.7586 & 21.5053 & 272.30 & 0.441 & 0.445 & 0.267 & 2.575 \\
\hline 9 & 107.7769 & 21.5049 & 191.88 & 0.342 & 0.328 & 0.192 & 2.039 \\
\hline 10 & 107.7706 & 21.4492 & 303.91 & 0.477 & 0.529 & 0.287 & 2.827 \\
\hline 11 & 107.8355 & 21.5007 & 166.24 & 0.330 & 0.328 & 0.189 & 1.983 \\
\hline 12 & 107.8369 & 21.4996 & 143.59 & 0.277 & 0.263 & 0.165 & 1.766 \\
\hline 13 & 107.8652 & 21.5188 & 264.60 & 0.397 & 0.414 & 0.243 & 2.318 \\
\hline 14 & 107.8516 & 21.5170 & 123.52 & 0.150 & 0.132 & 0.084 & 1.352 \\
\hline 15 & 107.9021 & 21.5190 & 266.94 & 0.428 & 0.440 & 0.251 & 2.494 \\
\hline 16 & 107.9011 & 21.5187 & 207.31 & 0.360 & 0.348 & 0.212 & 2.127 \\
\hline 17 & 107.9294 & 21.4629 & 134.86 & 0.250 & 0.225 & 0.139 & 1.667 \\
\hline 18 & 107.9281 & 21.4622 & 285.87 & 0.479 & 0.480 & 0.283 & 2.841 \\
\hline 19 & 108.0131 & 21.4952 & 335.59 & 0.567 & 0.606 & 0.347 & 3.618 \\
\hline 20 & 108.0118 & 21.4953 & 137.19 & 0.304 & 0.289 & 0.187 & 1.875 \\
\hline
\end{tabular}


The AGB of each sampling plot was calculated by taking an average AGB of 3 sub-plots, then scaling in tons $\mathrm{ha}^{-1}$. Four VIs were selected to develop the model of AGB calculation, including NDVI, $\mathrm{EVI}, \mathrm{SAVI}$, and SR. To construct the predictive models for mangrove AGB, R-studio software was used to develop biomass model estimation from different variables (SR, NDVI, SAVI and EVI). The result is shown in Table 7.

Table 7. The best models for the AGB estimation-based on Landsat-8 data and the plots inventory.

\begin{tabular}{|c|l|l|c|c|}
\hline Models & Variables & Equation for AGB (tons $\mathbf{~ h a}^{-1}$ ) & $\mathbf{R}^{\mathbf{2}}$ & $\mathbf{p}$-value \\
\hline 1 & $\mathrm{SR}$ & $\mathrm{AGB}=-12.12+106.38 * \mathrm{SR}$ & 0.869 & $<0.001$ \\
\hline 2 & $\mathrm{NDVI}$ & $\mathrm{AGB}=12.89+583.06 * \mathrm{NDVI}$ & 0.916 & $<0.001$ \\
\hline 3 & $\mathrm{EVI}$ & $\mathrm{AGB}=42.51+498.42 * \mathrm{EVI}$ & 0.922 & $<0.001$ \\
\hline 4 & $\mathrm{SAVI}$ & $\mathrm{AGB}=30.38+911.95 * \mathrm{SAVI}$ & 0.924 & $<0.001$ \\
\hline
\end{tabular}

The best model selected to estimate AGB from VIs is Model 4, which has the highest coefficient of determination $\left(R^{2}\right)$ (Table 7). This model was therefore used to estimate the AGB of mangrove forests for the whole study site. This AGB model was then evaluated based on 5 validation plots. The validation of selected AGB model is summarized in Table 8 .

Table 8. Validation of selected AGB estimation model over the coasts of the study site.

\begin{tabular}{|c|c|c|c|c|c|}
\hline Plots & Longitude & Latitude & $\begin{array}{l}\text { Field-based } \\
\text { AGB estimation } \\
\text { (tons } \text { ha }^{-1} \text { ) }\end{array}$ & $\begin{array}{l}\text { AGB-derived } \\
\text { model estimation } \\
\text { (tons } \mathrm{ha}^{-1} \text { ) }\end{array}$ & $\begin{array}{l}\text { Difference between } \\
\text { AGB estimation-derived } \\
\text { plots and model (\%) }\end{array}$ \\
\hline 4 & 107.6850 & 21.4029 & 331.8 & 327.6 & 1.3 \\
\hline 8 & 107.7586 & 21.5053 & 272.3 & 274.1 & 0.7 \\
\hline 12 & 107.8369 & 21.4996 & 143.6 & 181.1 & 26.1 \\
\hline 16 & 107.9011 & 21.5187 & 207.3 & 224.0 & 8.0 \\
\hline 20 & 108.0118 & 21.4953 & 137.2 & 201.1 & 46.6 \\
\hline \multicolumn{3}{|c|}{ Mean } & 218.4 & 241.6 & 16.0 \\
\hline \multicolumn{3}{|r|}{ Min } & 137.2 & 181.1 & 0.7 \\
\hline \multicolumn{3}{|r|}{ Max } & 331.8 & 327.6 & 46.6 \\
\hline
\end{tabular}

As indicated in Table 8, five validation plots, namely plots 4, 8, 12, 16, and 20, were selected for the model validation. They were used to compare the AGB estimation-based plot measurements and developed AGB models (Table 8). As a result, the difference between two model estimation approaches ranges from $0.7 \%$ to $46.6 \%$, with an average of $16.0 \%$. Therefore, it assumes that the selected model for AGB estimation is relatively appropriate and can be applicable over the coasts of Hai Ha District and Mong Cai City, Quang Ninh Province.

Based on the selected Model 4, the distribution of the AGB of mangrove forests was then estimated and presented in Fig. 6 . 


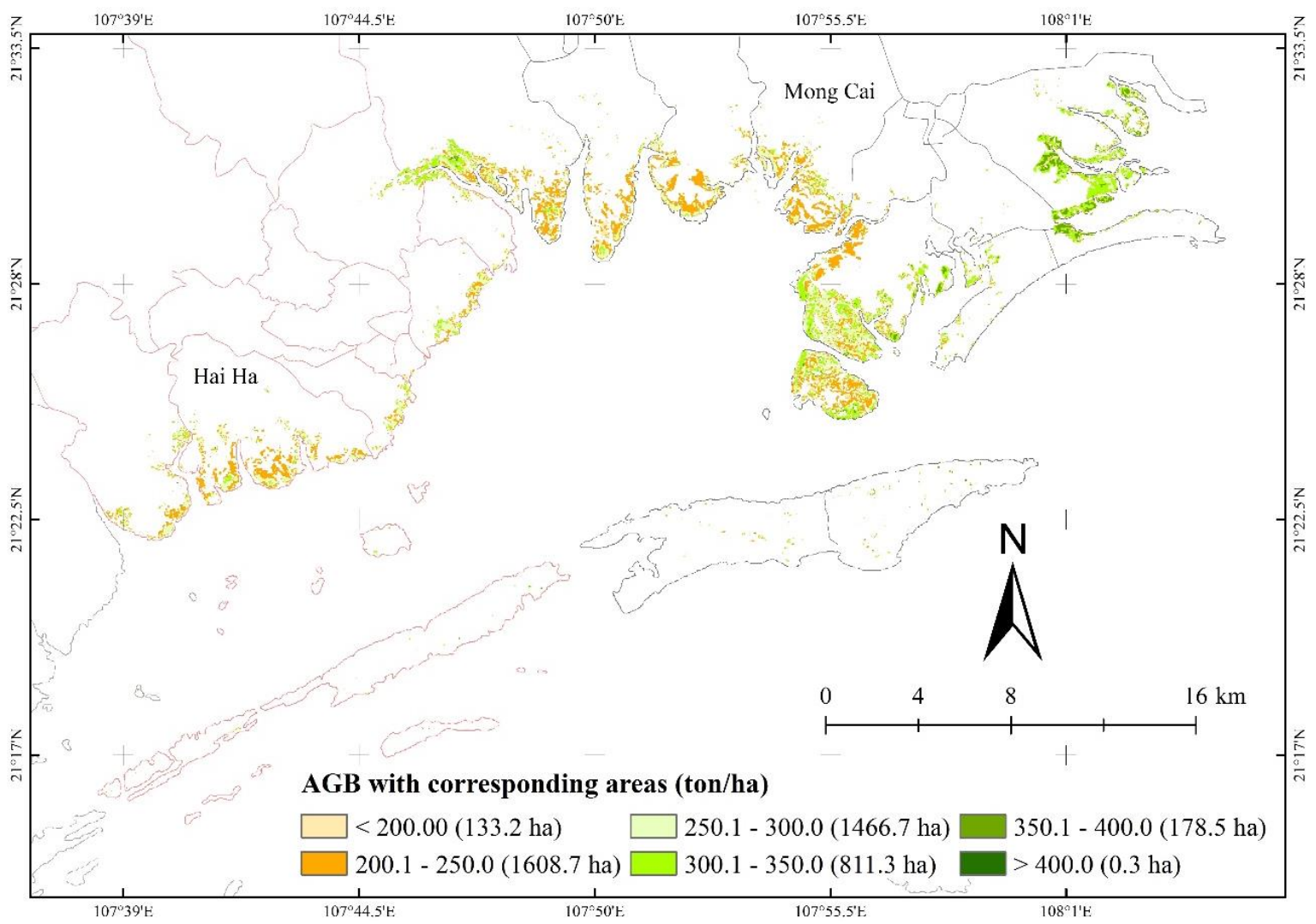

Figure 6. Spatial distribution of AGB categories corresponding areas over the coasts of Hai Ha and Mong Cai City. AGB values were classified into six categories: less than 200 tons ha ${ }^{-1}, 200-250$ tons ha $^{-1}, 250-300$ tons ha $^{-1}, 300-350$ tons ha $^{-1}$, and $350-400$ tons ha- ${ }^{-1}$, and greater than 400 tons ha1

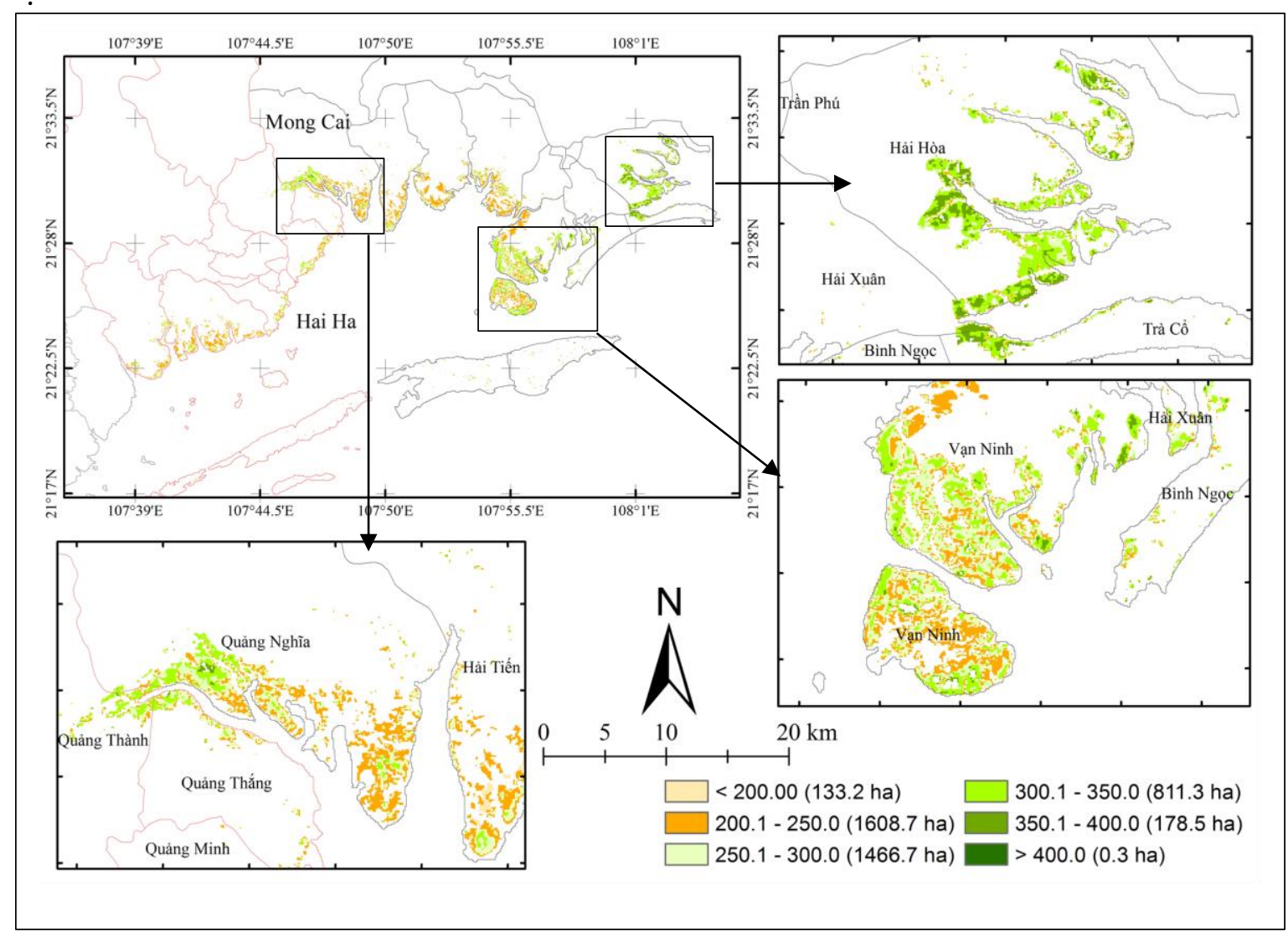

Figure 7. The AGB concentration of mangrove forests in key coastal communes of Mong Cai City, Quang Ninh Province. 
The total amount of the AGB of mangrove forests is estimated at $14,612,928$ tons in the study site. The lowest $A G B$ is 94.0 tons $\mathrm{ha}^{-1}$, and the highest $A G B$ is about 432.0 tons ha- ${ }^{-1}$. The concentration of AGB in Mong Cai City is higher than in Hai Ha District (Fig. 6 and Fig. 7). As shown in Fig. 7, Hai Hoa commune has the highest AGB concentration more than 300 tons ha $^{-1}$, followed by Van Ninh and Quang Nghia communes in Mong Cai coast (Fig. 7).

\subsubsection{Estimated AGC over the coasts of Hai Ha and Mong Cai}

To calculate the AGC of mangrove forests over the coasts of Hai Ha District and Mong Cai City, the study used the AGB of mangrove forests multiplied with a conversion ratio of 0.47 (Howard, et al., 2014). As a result, the overall AGC estimation of mangrove forests across all coastal mangrove communes is presented in Fig. 8.

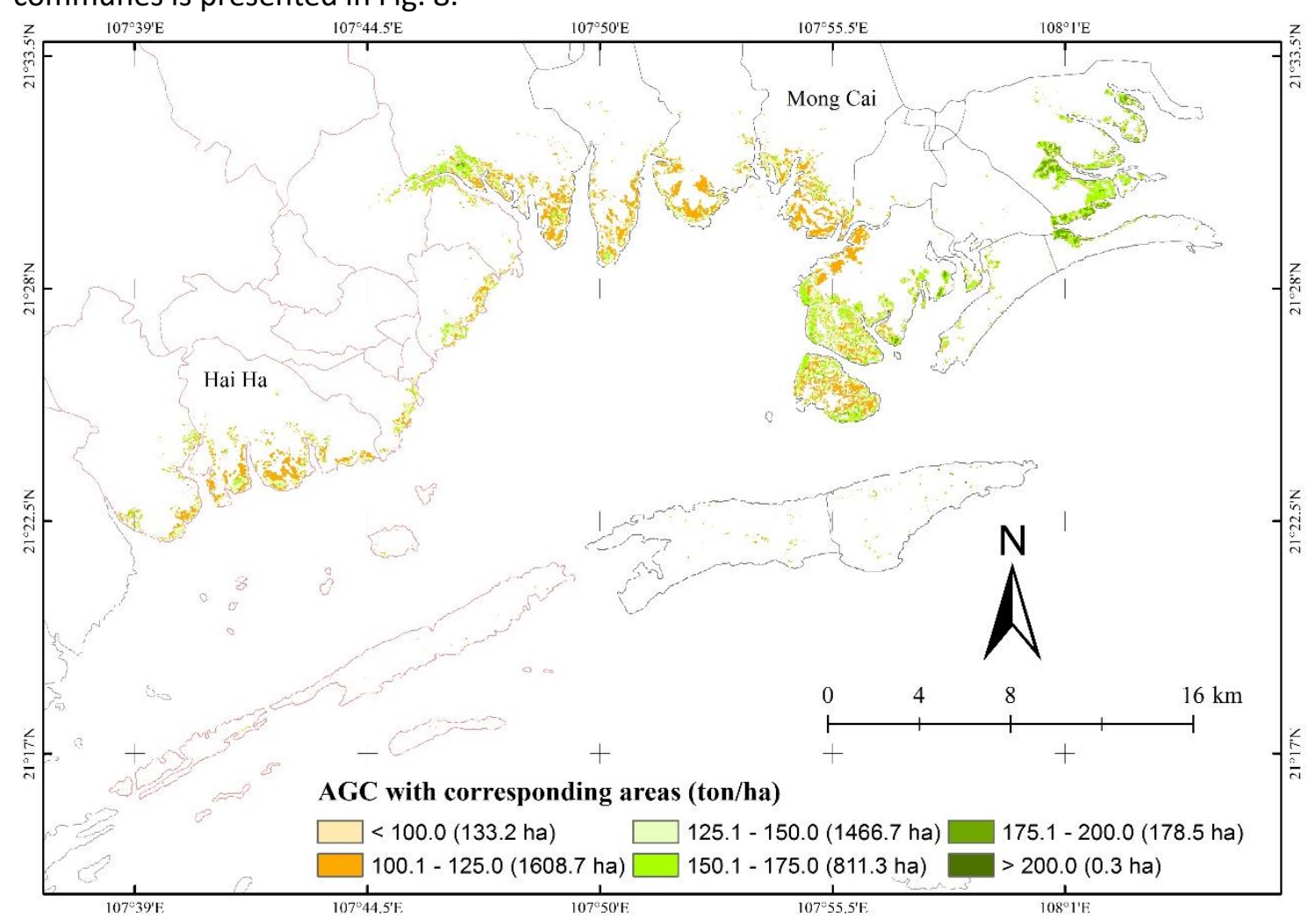

Figure 8. Spatial distribution of AGC categories corresponding areas over the coasts of Hai Ha and Mong Cai City. AGB values were classified into six categories: less than 100 tons ha ${ }^{-1}, 100-125$ tons $\mathrm{ha}^{-1}, 125-150$ tons ha- ${ }^{-1}, 150-175$ tons ha $^{-1}$, and $175-200$ tons ha $^{-1}$, and greater than 200 tons ha 1 .

The total amount of the AGC of mangrove forests is estimated at 6,868,076 tons in the study site. The lowest AGC is 44.19 tons ha- ${ }^{-1}$, and the highest AGC is about 203.02 tons ha- ${ }^{-1}$. Similar to the AGB estimation, Hai Hoa commune has the highest AGC concentration more than 150 tons ha ${ }^{-1}$, followed by Van Ninh and Quang Nghia communes in Mong Cai coast, while the low amount of AGC is recorded in most of the mangrove communes of Hai Ha District.

\subsection{Discussion}

Mangrove forests have a significant role in stabilizing the livelihoods of coastal people and protecting the coastal adjacent land uses from extreme events like storms and wave attacks. Using the remote sensing data, in particular freely downloaded sensing data as Landsat- 8 and Sentinel images can save time, budget and labor forces in monitoring changes of coastal land use and land covers (e.g. Hai-Hoa et al., 2013; Thuyet et al., 2014; Hai-Hoa et al., 2020a) and estimating AGB and AGC of mangrove forests (e.g. Pham et al., 2018; Wang et al., 2020; Hashim et al., 2020). This study surveyed the status of coastal land use and land covers, including mangrove forests along the coastline of Hai Ha District and Mong Cai City, Quang Ninh Province. The AGB models were 
developed and the most suitable AGB model was selected to estimate the overall AGB of the study site.

There were five types of land use and land covers identified, including mangrove forests, other vegetation, wetlands, built-up and water classes. The land use and land cover map in 2019 was constructed with an overall accuracy (80.0\% and Kappa coefficient of 0.74$)$, and classified mangrove forests reached at $78.6 \%$ of User's accuracy assessment. The classification result in this study is acceptable to compare with other previous studies (e.g. Dan et al., 2016; Tieng et al., 2019; Hai-Hoa et al., 2020b). A similar ISODATA clustering method was applied to classify mangrove forests in Philippines and the classification accuracy reached $96.6 \%$, with a Kappa coefficient of 0.926 (Long and Giri, 2011). Several factors that were affected the classification accuracy have been identified in this study site, including the mixed pixel issues, cloud coverage, spatial resolution issues like Landsat data, and tidal matters. Some areas of mangrove forests and rice-paddy fields possibly had led to the misclassification of land use and land cover due to the mixed pixel issues including pixels of soil, vegetation, and water in Landsat-8 image. This misclassification has been confirmed by many previous studies (e.g. Manandhar et al., 2009; Ai et al., 2020). In addition, some areas of wetlands had been classified as the wet and bare soil due to the low tidal effects (Zhang et al., 2019). In these 20 plots, there were 4 species have been identified, including Rhizophora stylosa, Avicennia marina, Aegiceras coniculatum, and Kandelia obovata. However, some other mangrove species were not included in the whole study site due to a small number of plots set up. According to the local forest rangers, other mangrove species might be found over the coasts of Hai Ha District and Mong Cai City, namely Sonneratia caseolaris and Bruguiera gymnorrhiza.

In this study, the total extent of mangrove forests was estimated at 4191.2 ha over the coasts of Hai Ha District and Mong Cai City. According to the report of local Forest Ranger, the entire extent of mangrove forests was 4079.6 ha in 2018. The difference in the extent of mangrove forests between 2018 and 2019 is about 111.6 ha. In fact, there were some mangrove plantation programs under the international and national initiatives projects, including Provincial and Vietnam Government Project and Red Cross and Japan International Cooperation Agency (JICA) programs during 2018- 2019 (Pham et al., 2019). Another factor may lead to the difference in mangrove extent between two years. Misclassification might be claimed as the difference, while other reasons might be due to the mangrove areas in Quang Dien Commune, belonged to Hai Ha District had not been included in a forest inventory of Forest Ranger since 2018.

The AGB models of mangrove forests were developed based on a combination of field investigation and VIs analysis from Landsat-8 image over the coasts of Hai Ha District and Mong Cai City. As results, four AGB models were generated based on four separated vegetation indices, including SR, NDVI, EVI and SAVI with $\mathrm{R}^{2}=0.869,0.916,0.622$, and 0.924 , respectively (Table 6 ). In general, four $A G B$ models are all very good levels of prediction with a high and very high coefficient of determination $\left(R^{2}\right)$, indicating the proportion of variance in the dependent variable (AGB) that can be explained by the independent variable (SR, NDVI, EVI or SAVI) (Nguyen et at., 2021). In addition, all models have the statistically significant values ( $P_{\text {value }}<0.001$ ), which show the independent variable is statistically significant for the prediction of the dependent variable and this means the adopted AGB model is a good fit of the data (Nguyen et al., 2021). In this study, the best model selected is $A G B=30.38+911.95 * S A V I$ with the highest coefficient of determination $\left(R^{2}=\right.$ 0.924). As a result, the difference in the amount of $A G B$ estimation-based field survey and the selected AGB model was acceptable, ranging from $0.7 \%$ to $46.6 \%$ of the AGB of mangrove forests, with an average of $16.0 \%$. Each type of mangrove forests has different characteristics in terms of species composition, density, and soil characteristics (e.g. Tinh et al., 2020; Sharma et al., 2020; Kauffman et al., 2020). Therefore, the predictive model selected should be applied only in this study or other similar coastal characteristics and mangrove composition. Other studies also have developed different models to predict the AGB and AGC of mangrove forests in their study areas. Therefore, it is suggested that different areas would apply the specific model with specific coefficients and parameters when estimate the AGB and AGC of mangrove forest from VIs. A general model cannot be accurate for a large scale. NDVI-derived from Landsat and SPOT-5 data was used to generate a model for estimating mangrove biomass in Malaysia (Hamdan et al., 2013). Bao and 
Hoa (2018) also selected NDVI, but from Sentinel-2, to estimate mangrove biomass in Hai Phong, Vietnam.

\subsubsection{Implication of C-PFES development in Quang Ninh Province:}

As the AGB model selected, the total $A G B$ and $A G C$ of mangrove forests were estimated at approximately $14,600,000$ tons and $6,868,076$ tons with a range of from $94.0-432.0$ tons ha $^{-1}$, from $44.2-203.02$ tons $\mathrm{ha}^{-1}$, respectively. This estimate is supported by previous studies at local and regional scale, including the total AGB from 211.8 - 460.0 tons ha $^{-1}$ in Malaysia (Ong et al., 1982; Putz and Chan, 1986; Goessens et al., 2014); 40.7 - 356 tons ha ${ }^{-1}$ in Indonesia (Kusmana and Sabiham, 1992); $62.2-298.5$ tons ha $^{-1}$ in Thailand (Komiyama et al., 1987; Kristensen et al., 1995); the mean highest $A G B$ in Southeast Asia and Pacific Islands with 230.9 and 233.3 tons ha ${ }^{-1}$, respectively, while the mean global AGB with 184.4 tons $^{-1}{ }^{-1}$ (Hutchison et al., 2014); the AGB of mangrove forest in Vietnam with a range of 38.8 - 523.6 tons ha ${ }^{-1}$ (e.g. Pham et al., 2017; Vinh et al., 2019; Thuy et al., 2020). Therefore, it is noted that the AGB model selected is applicable to estimate the AGC of mangrove forest for the coasts of Hai Ha District and Mong Cai City, Quang Ninh Province. The additional field plots should be provided to test whether the selected AGB model can be applied the remaining coastal areas of Quang Ninh Province.

The carbon market has been seen as the effective tool to reduce the $\mathrm{CO}_{2}$ emissions, one of the largest contributors of greenhouse gases. The carbon market mechanism is supported by four main mechanisms, clearly stated in the Kyoto Protocol, namely emissions trading mechanism, CDM (Clear Development Mechanism), JI (Joint Implementation) and REDD (Reducing Emissions from Deforestation and Forest Degradation, now is REDD+) (Hohne et al., 2015; Thuy et al., 2020). This study also suggests that the newly-developed AGB model of mangrove forests can be used to estimate AGC stocks and carbon sequestration of mangrove forests for C-PFES in over the coasts of Hai Ha District and Mong Cai City. From the AGB model selected, the study calculated the amount of absorbed carbon dioxide and the commercial values of mangrove forests in Hai Ha Coast and Mong Cai Coast as shown in Table 9.

Table 9. Absorbed carbon dioxide by mangrove forests and commercial values in the study site.

\begin{tabular}{|l|l|}
\hline & Absorbed $\mathrm{CO}_{2}$ \\
\hline Total absorbed $\mathrm{CO}_{2}$ & $250,205,838.92$ (tons) \\
\hline Price at the carbon market & $\$ 11$ ton $^{-1}$ (Thuy et al., 2020) \\
\hline Conversion (up to 08/07/2021) & $1 \mathrm{USD}=22,900.00$ VND* \\
\hline \multirow{2}{*}{ Total proceeds } & $\$ 277,264,228.12$ USD \\
& $6,349,350,823,948.00$ (VND) \\
\hline
\end{tabular}

* https://portal.vietcombank.com.vn/Pages/Home.aspx

In Vietnam, five the $\mathrm{CO}_{2}$ price varies from $\$ 5$ USD ton ${ }^{-1}$ to $\$ 10$ USD ton ${ }^{-1}$ depending on different type of forests. However, this study suggests the price of $\mathrm{CO}_{2}$ should be $\$ 11$ USD ton ${ }^{-1}$, which is based on the lowest $\mathrm{CO}_{2}$ price in the carbon market price (Thuy et al., 2020). The total $\mathrm{CO}_{2}$ of mangrove forests over the coasts of Hai Ha and Mong Cai was estimated around 250,205,838.92 tons (Table 8), only accumulated $\mathrm{CO}_{2}$ in the mangrove tree biomass, which have provided a strong evidence for Quang Ninh Province to enroll in the Payments for Environmental Forest Services and Carbon Credit Mechanism (C-PFES). The higher carbon stocks values are, the larger commercial values that mangrove forests are more likely to provide local people, which is the basis for the application of -PFES policy in study site (Phuong, 2006). This is a very importantly financial source for mangrove forest managers, in particular for local mangrove protectors over the coasts of Hai Ha District and Mong Cai City, Quang Ninh Province.

\section{Conclusion}

Remote sensing data, including Landsat- 8 data can be used for the AGB and AGC estimation of mangrove forests over the larger coastal areas compared to the conventional and traditional plot inventory only. The study used Landsat- 8 data for coastal land use and land cover mapping, including mangrove forests over the coasts of Hai Ha District and Mong Cai City, Quang Ninh Province. There were five land covers identified, including mangrove forests, other vegetation, wetlands, built-up, 
and water, with the overall accuracy assessments of $80.0 \%$ and Kappa coefficient of 0.74 . This assessment has confirmed that using a moderate spatial resolution data like Landsat- 8 image is reliable for mapping coastal land use and land cover. Based on the AGB estimation-based plots inventory and vegetation indices- derived from Landsat- 8 data, there were four suitable AGB estimation models shortlisted, which were based on the coefficient of determination $\left(R^{2}\right)$ and $P_{\text {value }}$ obtained, the best $A G B$ estimation model of $A G B=30.38+911.95 * S A V I\left(R^{2}=0.924, P_{\text {Value }}<0.001\right)$ was selected to estimate the $A G B$ and $A G C$ of mangrove forests for the whole coasts of Hai Ha District and Mong Cai City. The model validation assessment has shown that the selected AGB model can be applied to Hai Ha and Mong Cai coasts. In addition, the satisfactory AGB model also suggests a good potential for AGB and AGC mapping, which offer the carbon trading market in the study site. Besides, the selected AGB model is suggested to be tested with other similarly coastal areas of Quang Ninh Province with more additional provision of the field plots inventory to answer the question of whether the selected AGB model can be applied to other coastal areas or similar coastal conditions in Quang Ninh Province.

AcknowledgementsThis research is funded by Vietnam National Foundation for Science and Technology Development (NAFOSTED) under grant number 105.08-2017.05. The authors also would like to express the deepest appreciation to all forest rangers and local people in Hai Ha District and Mong Cai City for their assistance. We also appreciate the anonymous reviewers of the paper for their useful and constructive comments. The authors also thank the Department of Environmental Remote Sensing and Geoinformatics, University Trier, Germany; Department of Environmental Engineering, the Vietnam National University of Forestry for supporting us.

Conflicts of Interest: The authors declare no conflict of interest.

Funding: This research is funded by Vietnam National Foundation for Science and Technology Development (NAFOSTED) under grant number 105.08-2017.05.

\section{References}

Ai, J., Zhang, C., Chen, L., \& Li, D. (2020). Mapping annual land use and land cover changes in the Yangtze estuary region using objective-based classification framework and Landsat time series data. Sustainability, 12(2), 659. https://doi.org/10.3390/su12020659

Alongi, D. M. (2009). Introduction in the energetics of mangrove forests. Springer Science and Business Media.

Aksornkoae, S. (1993). Ecology and management of mangroves. Gland, Switzerland, IUCN, Wetlands and Water Resources Programme.

Bao, T. Q., \& Hoa, L. S. (2018). Using Sentinel satellite image to estimate biomass of mangrove forest in Vinh Quang commune, Tien Lang district, Hai Phong city. Journal of Forestry Science and Technology, 5, 71-79.

Blasco, F., Gauquelin, T., Rasolofoharinoro, M., Denis, J., Aizpuru, M., \& Caldairou, V. (1998). Recent advances in mangrove studies using remote sensing data. Marine and Freshwater Research, 49(4), 287-296. https://doi.org/10.1071/MF97153

Castillo, J. A. A., Apan, A. A., Maraseni, T. N., \& Salmo, III. S. G. (2017). Estimation and mapping of above-ground biomass of mangrove forests and their replacement land uses in the Philippines using Sentinel imagery. ISPRS Journal of Photogrammetry and Remote Sensing, 134, 70-85. https://doi.org/10.1016/j.isprsjprs.2017.10.016

Chander, G., Markham, B. L., \& Helder, D. L. (2009). Summary of Current Radiometric Calibration Coefficients for Landsat MSS, TM, ETM+, and EO-1 ALI Sensors. Remote Sensing of Environment, 113(5), 893-903. https://doi.org/10.1016/j.rse.2009.01.007

Chen, B., Xiao, X., Li, X., Pan, X., Doughty, R., Ma, J., Dong, J., Qin, Y., Zhao, B., Wu, Z., Sun., R., Lan, G., Xie, G., Clinton, N., \& Giri, C. (2017). A mangrove forest map of China in 2015: Analysis of time series Landsat 7/8 and Sentinel $1 \mathrm{~A}$ imagery in Google Earth Engine cloud computing platform. ISPRS Journal of Photogrammetry and Remote Sensing, 131, 104-210. https://doi.org/10.1016/j.isprsjprs.2017.07.011

Cissell, J. R., Delgado, A. M., Sweetman, B. M., \& Steinberg, M. K. (2018). Monitoring mangrove 
forest dynamics in Campeche, Mexico, using Landsat satellite data. Remote Sensing Applications: Society and Environment, 9, 60-68. https://doi.org/10.1016/j.rsase.2017.12.001

Dan, T. T., Chen, C. F., Chiang, S. H., \& Ogawa, S. (2016). Mapping and change analysis in mangrove forest by using Landsat imagery. ISPRS Annals of the Photogrammetry, Remote Sensing and Spatial Information Science, 8, 109-116. https://doi.org/10.5194/isprs-annals-III-8-109-2016

Donato, D. C., Kauffman, J. B., Murdiyarso, D., Kurnianto, S., Stidham, M., \& Kanninen, M. (2011). Mangroves among the most carbon-rich forests in the tropics. Nature Geoscience, 4(5), 293297. https://doi.org/10.1038/ngeo1123

Dube, T., Gara, T. W., Mutanga, O., Sibanda, M., Shoko, C., Murwira, A., ... \& Hatendi, C. M. (2018). Estimating forest standing biomass in savanna woodlands as an indicator of forest productivity using the new generation WorldView-2 sensor. Geocarto International, 33(2), 178-188. https://doi.org/10.1080/10106049.2016.1240717

Eggleston, H. S., Buendia, L., Miwa, K., Ngara, T., \& Tanabe, K. (2006). 2006 IPCC Guidelines for National Greenhouse Gas Inventories. IPCC National Greenhouse Gas Inventories Programme. Retrieved from http://www.ipcc-nggip.iges.or.jp/public/2006gl/index.htm

FAO. (2007). The World's Mangroves 1980-2005. FAO Forestry Paper 153. FAO.

Giri, C. (2016). Observation and monitoring of mangrove forests using remote sensing: Opportunities and challenges. Remote Sensing, 8(9), 783. https://doi.org/10.3390/rs8090783

Giri, C. (2021). Recent advancement in mangrove forests mapping and monitoring of the world using earth observation satellite data. Remote Sensing, 13(4), 563. https://doi.org/10.3390/rs13040563

Goessens, A., Satyanarayana, B., Van der Stocken, T., Zuniga, M. Q., Mohd-Lokman, H., Sulong, I., \& Dahdouh-Guebas, F. (2014). Is Matang mangrove forest in Malaysia sustainably rejuvenating after more than a century of conservation and harvesting management? PloS one, 9, e105069. https://doi.org/10.1371/journal.pone.0105069

Gupta, K., Mukhopadhyay, A., Giri, S., Chanda, A., Majumdar, S.D., Samanta, S., \& Hazra, S. (2018). An index for discrimination of mangroves from non-mangroves using LANDSAT 8 OLI imagery. MethodsX, 5, 1129-1139. https://doi.org/10.1016/j.mex.2018.09.011

Hai-Hoa, N., McAlpine, C., Pullar, D., Johansen, K., \& Duke, N. C. (2013). The relationship of spatialtemporal changes in fringe mangrove extent and adjacent land-use: Case study of Kien Giang coast, Vietnam. Ocean and Coastal Management, 76, 12-32. doi.org/10.1016/j.ocecoaman.2013.01.003

Hai-Hoa, N. (2014). The relation of coastal mangrove changes and adjacent land-use: A review in Southeast Asia and Kien Giang, Vietnam. Ocean and Coastal Management, 90, 1-10. http://dx.doi.org/10.1016/j.ocecoaman.2013.12.016

Hai-Hoa, N., \& Binh T. D. (2016). Using Landsat imagery and vegetation indices differencing to detect mangrove change: A case in Thai Thuy district, Thai Binh province. Journal of Forest Science and Technology, 5, 59-66.

Hai-Hoa, N., Nghia, N. H., Hien, N. T. T., An, L. T., Lan, T. T., Linh, D., Simone, B., \& Michael, F. (2020a). Classification Methods for Mapping Mangrove Extents and Drivers of Change in Thanh Hoa Province, Vietnam during 2005-2018. Forest and Society, 4(1), 225-242. https://doi.org/10.24259/fs.v4i1.9295

Hai-Hoa, N., Lan, T. T. N., An, L. T., Nghia, N. H., Linh, D. V. K., Hien, N. T. T., Bohm, S., \& Premnath, C. F.S (2020b). Monitoring changes in coastal mangrove extents using multi-temporal satellite data in selected communes, Hai Phong city, Vietnam. Forest and Society, 4(1), 256-720. https://doi.org/10.24259/fs.v4i1.8486

Hamdan, O., Khairunnisa, M. R., Ammar, A. A., Hasmadi, I. M., Aziz, H. K. (2013). Mangrove carbon stock assessment by optical satellite imagery. Journal of Tropical Forest Science, 25(4), 554565. https://www.jstor.org/stable/23616997

Hamdan, O., Azi, H. K., \& Hasmadi, I. M. (2014). L-band ALOS PALSAR for biomass estimation of Matang Mangroves, Malaysia. Remote Sensing of Environment, 155, 69-78. https://doi.org/10.1016/j.rse.2014.04.029

Hashim, T. M. Z. T., Suratman, M. N., Singh, H. R., Jaafar, J., \& Bakar, A. N. (2020, July). Predictive Model of Mangroves Carbon Stocks in Kedah, Malaysia using Remote Sensing. In IOP 
Conference Series: Earth and Environmental Science, 540(1), 012033. http://dx.doi.org/10.1088/1755-1315/540/1

Heumann, B. W. (2011). Satellite remote sensing of mangrove forests: Recent advances and future opportunities. Progress in Physical Geography, 35, 87-108. https://doi.org/10.1177\%2F0309133310385371

Hohne, N., Warnecke, C., Day, T., \& Roser, F. (2015). Carbon market mechanisms - Role in future international cooperation on climate change. New climate institute.

Howard, J., Hoyt, S., Isensee, K., Telszewski, M., \& Pidgeon, E. (2014). Coastal blue carbon: methods for assessing carbon stocks and emissions factors in mangroves, tidal salt marshes, and seagrasses. Conservation International, Intergovernmental Oceanographic Commission of UNESCO, International Union for Conservation of Nature, Arlington.

Huete, A., Didan, K., Miura, T., Rodriguez, E. P., Gao, X., \& Ferreira, L. G. (2002). Overview of the radiometric and biophysical performance of the MODIS vegetation indices. Remote Sensing of Environment, 83, 195-213. https://doi.org/10.1016/S0034-4257(02)00096-2

Hu, T., Zhang, Y., Su, Y., Zheng, Y., Lin, G., \& Guo, Q. (2020). Mapping the global mangrove forest aboveground biomass using multisource remote sensing data. Remote Sensing, 12(10), 1690. https://doi.org/10.3390/rs12101690

Nguyen, H. T. T., Hardy, G. E., Le, T. V., Nguyen, H. Q., Nguyen, H. H., Nguyen, T. V., \& Dell, B. (2021). Mangrove Forest Landcover Changes in Coastal Vietnam: A Case Study from 1973 to 2020 in Thanh Hoa and Nghe An Provinces. Forests, 12(5), 637. https://doi.org/10.3390/f12050637

Hutchison, J., Manica, A., Swetnam, R., Balmford, A., \& Spalding, M. (2014). Predicting global patterns in mangrove forest biomass. Conservation Letters, 7(3), 233-240. https://doi.org/10.3390/rs12101690

Hyyppä, J., Hyyppä, H., Inkinen, M., Engdahl, M., Linko, S., \& Zhu, Y.H. (2000). Accuracy comparison of various remote sensing data sources in the retrieval of forest stand attributes. Forest Ecology and Management, 128, 109-120. https://doi.org/10.1016/S0378-1127(99)00278-9

Jachowski, N. R., Quak, M. S., Friess, D. A., Duangnamon, D., Webb, E. L., \& Ziegler, A. D. (2013). Mangrove biomass estimation in Southwest Thailand using machine learning. Applied Geography, 45, 311-321. https://doi.org/10.1016/j.apgeog.2013.09.024

Kaufman, J. B., \& Donato, D. C. (2012). Protocols for the measurement, monitoring and reporting of structure, biomass and carbon stocks in mangrove forests. Working Paper 86. CIFOR. https://doi.org/10.17528/cifor/003749

Kauffman, J. B., Adame, M. F., Arifanti, V. B., Schile-Beers, L. M., Bernardino, A. F., Bhomia, R. K., ... \& Hernandez Trejo, H. (2020). Total ecosystem carbon stocks of mangroves across broad global environmental and physical gradients. Ecological Monographs, 90(2), e01405. https://doi.org/10.1002/ecm.1405

Komiyama, A., Poungparn, S., \& Kato, S. (2005). Common allometric equations for estimating the tree weight of mangroves. Journal of Tropical Ecology, 21(4), 471-477. https://doi.org/10.1017/S0266467405002476

Komiyama, A., Ogino, K., Aksornkoae, S., \& Sabhasri, S. (1987). Root biomass of a mangrove forest in southern Thailand. 1. Estimation by the trench method and the zonal structure of root biomass. Journal of Tropical Ecology, 3(2), 97-108. https://doi.org/10.1017/S0266467400001826

Kongwongjan, J., Suwanprasit, C., \& Thongchumnum, P. (2012). Comparison of vegetation indices for mangrove mapping using THEOS data. Proceedings of the Asia-Pacific Advanced Network, 33, 56-64. http://dx.doi.org/10.7125/APAN.33.6

Kovacs, J.M., Santiago, F. F., Bastien, J., \& Lafrance, P. (2010). An Assessment of Mangroves in Guinea, West Africa, using a Field and Remote Sensing Based Approach. Wetlands, 30, 773782. https://doi.org/10.1007/s13157-010-0065-3

Kristensen, E., Holmer, M., Banta, G. T., Jensen, M. H., \& Hansen, K. (1995). Carbon, nitrogen and sulfur cycling in sediments of the Ao Nam Bor mangrove forest, Phuket, Thailand: a review. Phuket Marine Biological Center Research Bulletin, 60, 37-64

Kuenzer, C., Bluemel, A., Gebhardt, S., Tuan V. Q., \& Dech, S. (2011). Remote Sensing of Mangrove Ecosystems: A Review. Remote Sensing, 3(5), 878-928. https://doi.org/10.3390/rs3050878 
Kumar, L., \& Mutanga, O. (2017). Remote sensing of above-ground biomass. Remote Sensing, 9(9), 935. https://doi.org/10.3390/rs9090935

Kusmana, C., \& Sabiham, S., (1992). An estimation of above ground tree biomass of a mangrove forest in East Sumatra, Indonesia. Tropics, 1, 243-257. https://doi.org/10.3759/tropics.1.243

Li, X., Gar-on Yeh, A., Wang, S., Liu, K., Liu, X., Qian, J., \& Chen, X. (2007). Regression and analytical models for estimating mangrove wetland biomass in South China using Radarsat images. International Journal of Remote Sensing, 28, 5567-5582. https://doi.org/10.1080/01431160701227638

Long, D. N., Cuong, T. N., Hoa, S. L., \& Bao, Q. T. (2019). Mangrove mapping and above-ground biomass change detection using satellite iamges in coastal areas of Thai Binh province, Vietnam. Forest and Society, 3(2), 248-261. https://doi.org/10.24259/fs.v3i2.7326

Long, J. B., \& Giri, C. (2011). Mapping the Philippines' mangrove forests using Landsat imagery. Sensors, 11(3), 2972-2981. https://doi.org/10.3390/s110302972

Lu, X. T., Yin, J. X., Jepsen, M. R., \& Tang, J. W. (2010). Ecosystem carbon storage and partitioning in a tropical seasonal forest in Southwestern China. Forest Ecology and Management, 260, 17981803. https://doi.org/10.1016/j.foreco.2010.08.024

Lugo, A. E., \& Snedaker, S. C. (1975). Properties of a mangrove forest in southern Florida. In G.E. Walsh, S.C. Snedaker \& M.J. Teas, eds. Proceedings of the International Symposium on Biology and Management of Mangroves (pp. 170-212). Gainesville, Florida, USA, University of Florida.

Manandhar, R., Odeh, I. O., \& Ancev, T. (2009). Improving the accuracy of land use and land cover classification of Landsat data using post-classification enhancement. Remote Sensing, 1(3), 330-344. https://doi.org/10.3390/rs1030330

Malarvizhi, K., Kumar, S. V., \& Porchelvan, P. (2016). Use of High-Resolution Google Earth Satellite Imagery in Land use Map Preparation for Urban Related Applications. Procedia Technology, 24, 1835-1842. https://doi.org/10.1016/j.protcy.2016.05.231

Nguyen, V. D., Hai-Hoa, N., Quyet, N., \& Duy Quang, P., (2021). Land surface temperature responses to vegetation and soil moisture index using Landsat-8 data in Luong Son District, Hoa Binh Province. Journal of Forest Science and Technology, 11, 1-13.

Norjamaki, I., \& Tokola, T. (2007). Comparison of atmospheric correction methods in mapping timber volume with multi-temporal Landsat images in Kainuu, Finland. Photogrammetric Engineering \& Remote Sensing, 73(2), 155-163. https://doi.org/10.14358/PERS.73.2.155

Ong, J. E., Malaysia, U. S., Gong, W. K., \& Wong, C. H. (1982). Studies on Nutrient Levels in Standing Biomass, Litter and Slash in a Mangrove Forest. School of Biological Sciences, Universiti Sains Malaysia.

Pham, T. D., \& Yoshino, K. (2017). Aboveground biomass estimation of mangrove species using ALOS-2 PALSAR imagery in Hai Phong City, Vietnam. Journal of Applied Remote Sensing, 11(2), 026010. https://doi.org/10.1117/1.JRS.11.026010

Pham. T. D., Yoshino, K., Le, N. N., \& Bui, D. T. (2018). Estimating aboveground biomass of a mangrove plantation on the Northern coast of Vietnam using machine learning techniques with an integration of ALOS-2 PALSAR-2 and Sentinel-2A data. International Journal of Remote Sensing, 39(22), 7761-7788. https://doi.org/10.1080/01431161.2018.1471544

Pham, T. D., Le, N. N., Ha, N. T., Nguyen, L. V., Xia, J., Yokoya, N., To, T. T., Trinh, H. X., Kieu, L. Q., \& Takeuchi, W. (2020). Estimating Mangrove Above-Ground Biomass Using Extreme Gradient Boosting Decision Trees Algorithm with Fused Sentinel-2 and ALOS-2 PALSAR-2 Data in Can Gio Biosphere Reserve, Vietnam. Remote Sensing 12(5) 777. https://doi.org/10.3390/rs12050777

Pham, T. T., Phuong, V. T., Chien, P. D., Trang, D. L. H., Truong, N. V., Hoa, H. N. V., Long, H. T., Chi, D. T. T., \& Tien, N. D., (2019). Opportunities and challenges for mangrove management in Vietnam: Lessons learned from Thanh Hoa, Thai Binh and Quang Ninh provinces. Occasional Paper 197. CIFOR. https://doi.org/10.17528/cifor/007404

Phuong, V. T. (2006). Environmental value and environmental services. Journal of Agriculture and Rural Development, 15, 7-11.

Putz, F. E., \& Chan, H. T. (1986). Tree growth, dynamics, and productivity in a mature mangrove forest in Malaysia. Forest Ecology and Management, 17(2-3), 211-230. 
https://doi.org/10.1016/0378-1127(86)90113-1

Quang Ninh FPD (Quang Ninh Forest Protection Department). (2018). http://kiemlamqni.org.vn

Ramdani, F., Rahman, S., \& Giri, C. (2018). Principal polar spectral indices for mapping mangroves forest in South East Asia: study case Indonesia. International Journal of Digital Earth, 12(10), 1103-1117. https://doi.org/10.1080/17538947.2018.1454516

Saleh, M. (2007). Mangrove vegetation on Abu Minqar Island of the Red Sea. International Journal of Remote Sensing, 28(23), 5191-5194. https://doi.org/10.1080/01431160500391932

Sharma, S., MacKenzie, R. A., Tieng, T., Soben, K., Tulyasuwan, N., Resanond, A., ... \& Litton, C. M. (2020). The impacts of degradation, deforestation and restoration on mangrove ecosystem carbon stocks across Cambodia. Science of the Total Environment, 706, 135416. https://doi.org/10.1016/j.scitotenv.2019.135416

Sinha, S., Jeganathan, C., Sharma, L. K., Nathawat, M. S. (2015). A review of radar remote sensing for biomass estimation. International Journal of Environmental Science and Technology, 12, 1779-1792. https://doi.org/10.1007/s13762-015-0750-0

Steininger, M. (2000). Satellite estimation of tropical secondary forest above-ground biomass data from Brazil and Bolivia. International Journal of Remote Sensing, 21, 1139-1157. https://doi.org/10.1080/014311600210119

Stringer, C. E., Trettin, C. C., Zarnoch, S. J., \& Tang, W. (2015). Carbon stocks of mangroves within the Zambezi River Delta, Mozambique. Forest Ecology and Management, 354, 139-148. https://doi.org/10.1016/j.foreco.2015.06.027

Tinh, P. H., Hanh, N. T. H., Thanh, V. V., Tuan, M. S., Quang, P. V., Sharma, S., \& Mackenzie, A. (2020). A comparison of soil carbon stocks of intact and restored mangrove extents in Norhern Vietnam. Forests, 11(6), 660. https://doi.org/10.3390/f11060660

Tieng, T., Sharma, S., Mackenzie, R. A., Venkattappa, M., Sasaki, N. K., \& Collin, A. (2019, April). Mapping mangrove forest cover using Landsat-8 imagery, Sentinel-2, very high resolution images and Google Earth Engine Algorithm for entire Cambodia. IOP Conference Series: Earth and Environmental Science, 266(1), 012010. http://dx.doi.org/10.1088/1755$1315 / 266 / 1 / 012010$

Timothy, D., Onisimo, M., Cletah, S., Adelabu, S., \& Tsitsi, B. (2016). Remote sensing of aboveground forest biomass: A review. Tropical Ecology, 57(2), 125-132.

Thuy, H. L. T., Tan, M. T., Van, T. T. T., Bien, L. B., Ha, N. M., \& Nhung, N. T. (2020). Using Sentinel image data and plot survey for the assessment of biomass and carbon stocks in coastal forests of Thai Binh Province, Vietnam. Applied Ecology and Environmental Research, 18(6), 74997514. http://dx.doi.org/10.15666/aeer/1806_74997514

Bui, T. D., Maier, S. W., \& Austin, C. M. (2014). Land cover and land use change related to shrimp farming in coastal areas of Quang Ninh, Vietnam using remotely sensed data. Environmental Earth Sciences, 72(2), 441-455. https://doi.org/10.1007/s12665-013-2964-0

Thom, B. G. (1984). The mangrove ecosystem: research methods. The mangrove ecosystem: research methods. In S.C. Snedaker and J.G. Snedaker (Eds.) Monographs on oceanographic methodology (pp. 3-15). UNESCO.

Tue, N. T., Dung, L. V., Nhuan, M. T., \& Omori, K. (2014). Carbon storage of a tropical mangrove forest in Mui Ca Mau National Park, Vietnam. Catena, 121, 119-126. https://doi.org/10.1016/j.catena.2014.05.008

Tomlinson, P. B. (1986). The botany of mangroves. Cambridge University Press.

Nam, V. N., Sasmito, S. D., Murdiyarso, D., Purbopuspito, J., \& MacKenzie, R. A. (2016). Carbon stocks in artificially and naturally regenerated mangrove ecosystems in the Mekong Delta. Wetlands Ecology and Management, 24(2), 231-244. https://doi.org/10.1007/s11273-015-9479-2

Van Vinh, T., Marchand, C., Linh, T. V. K., Vinh, D. D., \& Allenbach, M. (2019). Allometric models to estimate above-ground biomass and carbon stocks in Rhizophora apiculata tropical managed mangrove forests (Southern Viet Nam). Forest Ecology and Management, 434, 131-141. https://doi.org/10.1016/j.foreco.2018.12.017

Wang, D., Wan, B., Liu, J., Su, Y., Guo, Q., Qiu, P., \& Wu, X. (2020). Estimating aboveground biomass of mangrove forests on northeast Hainan Island in China using an upscaling method from field plots, UAV-LiDAR data and Sentinel-2 imagery. International Journal of Applied Earth 
Observation and Geoinformation, 85. https://doi.org/10.1016/j.jag.2019.101986

Zhang, K., Dong, X., Liu, Z., Gao, W., Hu, Z., \& Wu. G. (2019). Mapping tidal flats with Landsat-8 images and Google Earth Engine: A case study of the China's Eastern coastal zone circa 2015. Remote Sensing, 11(8), 924. https://doi.org/10.3390/rs11080924 